УДК 94(420).08+94(493)



\title{
Образ Бельгии как «жертвы» в британской пропаганде периода Первой мировой войны
}

\author{
П.В. Ульянов
}

Алтайский государственный университет (Барнаул, Россия)

\section{The Image of Belgium as a "Victim" in British Propaganda of the First World War Period}

\author{
P.V. Ulyanov
}

Altai State University (Barnaul, Russia)

Рассматривается вопрос о создании образа Бельгии как «жертвы германской агрессии» во время Первой мировой войны. Данный образ был одним из средств воздействия на сознание британцев и побуждения их к вступлению в вооруженные силы Соединенного Королевства, чтобы бороться с Германией как с «внешней угрозой». Для оправдания собственных действий по вынужденному применению вооруженной силы и предотвращению агрессии, вызванной интервенцией немецких войск на территорию Бельгии, в британской периодической печати получил распространение сюжет об «ее изнасиловании». В современной исторической науке, особенно британской, этот вопрос широко изучается. Однако ученые-историки при его исследовании не учитывают всеобъемлющий характер этого агитационного сюжета. Поэтому автор ставит целью рассмотреть сюжет об «изнасиловании Бельгии» в контексте развития «образа жертвы» в британской пропаганде периода Первой мировой войны. Основная задача заключается в выявлении особенностей его влияния на процесс формирования целостного образа Германии как «внешнего врага». Проведенное исследование позволяет сделать вывод, что сформированный в период военного конфликта образ Бельгии как «жертвы германской агрессии» в пропаганде носил всеобъемлющий характер. В результате сложившийся целостный сюжет об «ее изнасиловании» стал одним из основных пропагандистских сюжетов на протяжении Первой мировой войны.

Ключевые слова: образ Бельгии, пропаганда, «образ врага», пропаганда в Великобритании, Первая мировая война.

\section{DOI 10.14258/izvasu(2019)2-13}

The article deals with the development of the image of Belgium as a "victim of German aggression" during the First World War. This image was one of the means of influencing the British consciousness and urging them to join the armed forces of the United Kingdom in order to fight Germany as an "external threat". To justify their own actions on the forced use of armed force and to prevent aggression caused by the intervention of the German troops in Belgium, the British periodical published a story about "its rape". In modern historical science, especially British, this issue is widely studied. However, historians in his study did not take into account the comprehensive nature of this campaign story. Therefore, the author aims to consider the plot of the "rape of Belgium" in the context of the development of the "victim image" in the British propaganda of the First World War. The main task is to identify the features of its influence on the process of forming a holistic image of Germany as an "external enemy". The study conducted allows us to conclude that the image of Belgium formed as a "victim of German aggression" in propaganda formed during the military conflict was comprehensive. As a result, the established holistic storyline about "its rape" became one of the main propaganda stories during the First World War.

Key words: the image of Belgium, propaganda, the "image of the enemy", propaganda in the UK, the First World War. 
В исторической науке при изучении истории Первой мировой войны ученые нередко обращаются к вопросам пропаганды и ее содержания. Последнее включает в себя различные агитационные сюжеты. Наиболее ярким из них в британской пропаганде периода Первой мировой войны стал сюжет об «изнасиловании Бельгии». Зарубежная историография темы включает в себя общие работы по Первой мировой войне и труды по пропаганде образа Бельгии в качестве «жертвы». К этой теме обращались британские историки М. Гилберт [1], Дж. Киган [2], Б. Лиддел Гарт [3], М. Сандерс [4, p. 119-146; 5] и П. Тэйлор [5], французские ученые Ж.-Ж. Беккер [6] и Ж.-С. Монтан [7, p. 135-143], а также американские исследователи Н. Гуллейс [8, р. 714-747] и Л. Зукерман [9]. Они подчеркивали, что сюжет об «изнасиловании Бельгии» оказал значительное влияние на формирование образа Германии, в результате чего ее агрессия воспринималась основной причиной вступления Великобритании в войну. Но они не ставили своей целью подробно показать влияние сюжета на формирование образа кайзера, государства и народа, тем самым не учитывали его всеобъемлющий характер.

В российской историографии, как и в зарубежной, собраны работы как по Первой мировой войне, так и по пропаганде. В ней стоит выделить труды Н.Ю. Забелиной [10, с. 85-94], Н.В. Залеток [11, с. 50-65], В.Б. Миронова [12], О.С. Поршневой [13, с. 15-30.] и Н.В. Юдина [14]. По их мнению, данный сюжет выполнял функцию мотивации населения на борьбу с «внешней угрозой» и поддержания патриотических и антигерманских настроений. В результате анализа историографии можно сказать, что в обоих направлениях поставленная нами проблема изучена слабо и не содержит комплексного подхода к ее исследованию. Поэтому, опираясь на выводы ученых-историков, проанализируем сюжет об «изнасиловании Бельгии» и выявим особенности его влияния на формирование образа Германии как «врага». Новизна работы заключается в комплексном рассмотрении влияния этого сюжета пропаганды на формирование образа Бельгии в качестве «страны-жертвы» в целом.

В исторической науке эта тема имеет актуальность, так как позволяет провести сравнительноисторический анализ британского опыта формирования образов «агрессора» и его «жертвы» периода начала XX в. и политики стран Европы и США на современном этапе. Внешнеполитическая деятельность не только Великобритании, но и других стран сегодня содержит в себе признаки целенаправленной пропаганды этих образов. Связано это с конкретными событиями, происходящими как на мировой арене, так и в отдельно взятой стране. Пропаганда образов «агрессора» и «жертвы» проводится государствами для оправдания собственных действий с целью достижения определенных результатов.

В статье делается попытка проанализировать проявление этой тенденции в период Первой мировой войны на примере Великобритании. Основным методом исследования является традиционный анализ исторических источников. В качестве таковых нами изучены материалы агитационной направленности (плакаты, карикатуры, листовки и прокламации, речи общественно-политических деятелей), источники личного характера (мемуары и дневники) и периодическая печать (газеты и журналы). За счет инвент-анализа и ситуационного анализа мы рассматриваем признаки германофобии в пропагандистской деятельности агитаторов по формированию «образа врага» в британском обществе, осуществляемой под влиянием различных факторов. Полученные результаты будут учитываться при написании научно-исследовательской работы.

Для начала обратимся к зарождению идеи сюжета об «изнасиловании Бельгии». Еще накануне вооруженного конфликта внешнеполитическая концепция правительства Великобритании основывалась на формировании сплоченного союза Соединенного Королевства с Францией и Бельгией. В связи с развитием англо-германского антагонизма британское правительство поставило своей целью оказать всевозможное давление на Германию в случае начала боевых действий с ее стороны. При этом Бельгия в противостоянии между Антантой и Тройственным союзом придерживалась позиции нейтралитета, что было выгодно Великобритании. В случае интервенции германских войск на территории нейтрального государства Соединенное Королевство выполнило бы взятые на себя обязательства и применило вооруженную силу в качестве ответной меры на проявление агрессии со стороны Германии. Британский историк Дж. Киган подчеркивал, что в этом случае вся ответственность за интервенцию своих вооруженных сил на территорию суверенного государства всецело легла бы на Германскую империю [2, p. 92]. Поэтому премьер-министр Великобритании Г. Асквит, выступая в палате общин 4 августа 1914 г., информировал депутатов об игнорировании Германией британской позиции по сохранению нейтралитета Бельгии [15, p. 97]. После отказа германского правительства отвечать на ультиматум британского правительства Великобритания 4 августа 1914 г. объявила Германии войну, и в стране начались всеобщая мобилизация и централизованная пропаганда.

Бельгийский сюжет был направлен на привлечение внимания широких масс, в основном мужского населения призывного возраста, и пробуждения у них интереса к вооруженному конфликту. Основной задачей была мотивация британцев на борьбу с «внеш- 
ней угрозой» в лице Германии. Поэтому вступление Великобритании в войну против этого государства правительство оправдывало, продвигая в массы представление о Бельгии как «о жертве германской агрессии». Однако в ходе пропаганды «образ жертвы» приобрел всеобъемлющий характер и стер представления о разнице между мирными жителями Германии и немецкими солдатами.

В то время как германская армия совершала интервенцию на территории нейтральной Бельгии, что было расценено британским правительством как акт агрессии, в речи британского политического деятеля Д. Ллойд Джорджа уже создавался образ Германии как «инициатора мировой бойни» [16, с. 11-12]. В другой своей речи политик побуждал мужское население вступать в ряды вооруженных сил Соединенного Королевства, оправдывая применение физической силы по отношению к «врагу» [17, с. 61-65]. Таким образом, был создан пропагандистский сюжет об «изнасиловании Бельгии». В результате Бельгия приобрела персонифицированный «образ женщины», подвергшейся нападению со стороны кайзера Вильгельма II. Так, в сатирическом журнале "Punch" женский образ Бельгии отражен на двух важных для нас карикатурах. На первой художник изобразил женщину, которую кайзер тащит в темницу [18, p. 137]. На другой Бельгия в «образе плененной женщины» уже была прикована Вильгельмом II цепями [19, р. 239]. В обоих случаях кайзер олицетворял «злого тюремщика», в то время как «женщина» изображалась «его пленницей». Кроме того, сюжеты этих карикатур отражают захватнические устремления правителя Германии и подчеркивают в нем черты агрессора и завоевателя.

Более убедительным и показательным примером стало убийство на территории Бельгии немецкими солдатами британской сестры милосердия Эдит Кэвелл. Посредством громкоговорителей и радио общество было оповещено о зверском убийстве, а само событие было отражено на одном из плакатов [20]. В британском обществе этот акт был расценен как зверство, отчего персонифицированный образ Бельгии как «изнасилованной женщины» приобрел конкретный характер и стал ассоциироваться с «сестрой-мученицей» Э. Кэвелл, принесшей себя в жертву ради победы над Германией. Это стало своеобразным мотивационным стимулом для британских солдат, поскольку под влиянием такого сюжета солдаты преодолевали социальное табу на убийство и применяли во время боя физическую силу по отношению к «немцу-врагу».

В распространении антинемецких настроений активную роль играла пресса. Так, в британской газете «The Daily Mail» Германия обвинялась в проявлении агрессии по отношению к нейтральной Бельгии, на- рушению принципа ее суверенности и посягательстве на независимость страны [21, p. 87]. Подобный правовой аспект был методом оправдания, который сочетался с антигерманскими взглядами. В этой же газете А. Кроули написал, что главной целью немецкого философа Ф. Ницше, ассоциируемого с «военизированной» Германией, было разрушение европейских моральных принципов, существовавших около двух тысяч лет [22, p. 40]. В этом плане Бельгия рассматривалась «беззащитной» и не способной оказать сопротивление государству, построенному на принципах военной мощи и насилии. Правовой аспект в британской прессе фактически был основан на отстаиваемой во время войны защитнической позиции Великобритании в отношении Бельгии, ставшей целью захватнических устремлений германского правительства.

Целенаправленная пропаганда «образа жертвы» не обошлась без упоминания в прессе зверств германских солдат, совершенных на территории Бельгии. Так, например, английский писатель А. Конан Дойл в газете «The Times» в качестве примера приводил издевательства германских солдат над мирным населением [23, с. 317-319], а самих немцев изображал в «образах зверей», придавая им дегуманизированные черты [24, с. 320]. Вдобавок сюжеты о зверствах были перенесены на британские рисунки, которые показывали германских солдат, проявляющих жестокость по отношению к женщинам и детям. При этом изображение в центре композиции просящей помощи и защиты от «германских варваров» женщины наглядно призывает к проявлению враждебности по отношению к германскому солдату [25].

Агитационные призывы предотвратить захватнические устремления кайзера и его военизированного правительства, остановить продвижение немецких войск и защитить Бельгию от них были отражены в листовках, предназначенных для распространения среди не только жителей Великобритании и морских владений, но и среди германских солдат на фронте. На территории Соединенного Королевства авторы в листовках делали акцент на совершенном в отношении «мирной» и «слабой» Бельгии злодеянии немецкими «воинскими легионами» [26, р. 17]. Британское правительство посредством листовок призывало население подвластных Великобритании территорий к сплочению против «внешней угрозы», в том числе и Британской Индии, продвигая идею «содружества наций» [27, р. 20]. На фронте среди немецких солдат распространялась информация об оправдании собственных действий британской армии в отношении Германии и ее войск и объяснении того, что Великобритания защищает Бельгию как «жертву войны» и не имеет завоевательных намерений как в отношении нее, так и в отношении Германии [28, p. 40]. 
С 1916 г. сюжет об «изнасиловании Бельгии» всецело использовался в обосновании концепции «борьбы до победного конца» премьер-министра Д. Ллойд Джорджа [29, с. 279]. Основная цель его заключалась в оказании информационного воздействия посредством листовок, газет и радио на Германию и ее политическую элиту, чтобы заставить нести ответственность за развязывание «мировой бойни» против «нейтральной» Бельгии и всего мира и за совершенные преступления против мирного населения на ее территории и всего человечества в целом [30, с. 182].

Таким образом, образ Бельгии как «жертвы агрессии» в пропаганде приобрел всеобъемлющий характер, в результате чего сложился целостный сюжет об «изнасиловании Бельгии». В свою очередь он имел несколько особенностей. Во-первых, пропагандистский сюжет всецело отражал комбинированный образ Германии, который включал в себя представления о «кайзере-завоевателе», «милитаризированном» государстве и о немецком солдате как «варваре» и «звере». В нем комплексно сочетались черты англо-германского антагонизма, антигерманские и антинемецкие настроения и правовые аспекты, которые были основой либеральной британской общественности. Во-вторых, он продвигался в массы за счет различных средств пропаганды с целью доказать правомерность действий британской армии, введенной на территорию независимой Бельгии для защиты ее и бельгийцев от немецких «солдат-оккупантов». В-третьих, сюжет был одним из средств воздействия на массовое сознание, прежде всего на мужскую аудиторию, с целью манипулирования ею и ожидания ответной реакции на сложившуюся военно-политическую обстановку. Следовательно, пропагандистский сюжет об «изнасиловании Бельгии» был многоплановый по своему характеру.

В целом апелляция к патриотическому чувству в пропаганде была связана с целями военной мобилизации во всех странах-участницах из-за сложившейся внешнеполитической обстановки накануне войны и взятыми на себя союзническими обязательствами между странами Антанты и Тройственного союза. Спецификой самой пропаганды «образа жертвы» в Великобритании был грамотно подобранный сюжет, который отражал правомерность введения войск на территорию союзного государства для защиты его целостности и присущих ему ценностей демократии.

\section{Библиографический список}

1. Гилберт М. Первая мировая война. М., 2016.

2. Keegan J. The First World War. L., 2014.

3. Лиддел Гарт Б. История Первой мировой войны. М., 2014.

4. Беккер Ж.-Ж. Первая мировая война. М., 2010.

5. Sanders M.L. Wellington House and British Propaganda during the First World War // The Historical Journal. 1975. Vol. 18, № 1.

6. Sanders M.L., Taylor P.M. British Propaganda during the First World War, 1914-1918. L., 1982.

7. Montant J.-C. Lorganisation centrale des services d'informations et de propaganda du Quari d'Orsay prendant la Grande guerre // Les sociétés européenes et la guerre de 1914-1918. P., 1990.

8. Gullase N.F. Sexual Violence and Family Honor: British Propaganda and International Law during the First World War // American Historical Review. 1997. Vol. 102. № 3.

9. Zuckerman L. The Rape of Belgium: The Untold Story of World War I. N.Y., 2004.

10. Забелина Н.Ю. Бельгийские союзники в восприятии британцев во время Первой мировой войны // Вестник Московского университета. Серия 8: История. 2010. № 1.

11. Залеток Н.В. Британские женщины в годы Первой мировой войны // Genesis: Исторические исследования. 2015. № 2.
12. Миронов В.Б. Первая мировая война. Борьба миров. М., 2014.

13. Поршнева О.С. Идея войны в практиках мобилизаций национального сознания европейских народов накануне Первой мировой войны: некоторые итоги изучения // Вопросы всеобщей истории. Т. 10. Екатеринбург, 2008.

14. Юдин Н.В. Патриотический подъем в странах Антанты в начале Первой мировой войны. М., 2017.

15. Statement by the Prime Minister in the House of Commons, August 4, 1914 // Great Britain and the European Crisis. Correspondence, and Statements in Parliament, Together with an Introductory Narrative of Events. L., 1914.

16. Ллойд Джордж Д. Через ужасы - к победе! (Речь, произнесенная 19 сентября 1914 года в Лондоне) // Речи, произнесенные во время войны. Воспоминания. Мемуары. Минск, 2003.

17. Ллойд Джордж Д. Правота нашего дела (Речь, произнесенная 10 ноября 1914 года) // Речи, произнесенные во время войны. Воспоминания. Мемуары. Минск, 2003.

18. The Knightly Manner // Punch. 1917. Vol. 153 [Electronic resource]. URL: https://archive.org/details/ punchvol152a153lemouoft/page/564 (дата обращения: 14.01.2019). 
19. The Belgian "Menace" // Punch. 1917. Vol. 153. [Electronic resource]. URL: https://archive.org/details/ punchvol152a153lemouoft/page/666 (дата обращения: 14.01.2019).

20. Archive Relating to Hero WW1 Nurse Executed by Germans Up for Auction [Electronic resource]. URL: http:// www.mylook.co/english/archive-relating-to-hero-ww1nurse-executed-by-germans-up-for-auction_9173655 (дата обращения: 14.01.2019).

21. Belgium's Case Against Germany. Revelations in Official Correspondence // The Daily Mail Year Book for 1915. L., 1915.

22. Crawley A.E. Nietzsche and Germany // The Daily Mail Year Book for 1915. L., 1915.

23. Конан Дойл А. Германская политика: ставка на убийство // Уроки жизни. М., 2003.
24. Конан Дойл А. Об отношении к военнопленным // Уроки жизни. М., 2003.

25. Британская антигерманская пропаганда в Первой мировой войне [Electronic resource]. URL: http://maxpark. com/community/5325/content/2328575 (дата обращения: 14.01.2019)

26. It Is a Privilege to Write... // King Albert's Book. L., 1914.

27. No Nation Has Regarded... // King Albert's Book. L., 1914.

28. The Conscience of the Whole... // King Albert's Book. L., 1914.

29. Берти Ф. За кулисами Антанты: дневник британского посла в Париже. 1914-1919. М., 2014.

30. Бьюкенен Дж. Мемуары дипломата. М., 1991. 